\title{
PRIMENA INFORMACIONIH TEHNOLOGIJA U FORMIRANJU PREMIJE ŽIVOTNIH OSIGURANJA
}

\section{APPLICATION OF INFORMATION TECHNOLOGIES IN PRICING LIFE INSURACE PREMIUM}

\author{
Pavle Mihajlović, Fakultet tehničkih nauka, Novi Sad
}

\begin{abstract}
Oblast - INŽENJERSKI MENADŽMENT
Kratak sadržaj - U ovom radu su prikazane osnove životnih osiguranja, način obračuna premije životnih osiguranja i primena IT-a u formiranju premije životnih osiguranja.
\end{abstract}

Ključne reči: Informacione tehnologije, premija osiguranja, programski jezik Python, tablice smrtnosti, životno osiguranje

\begin{abstract}
This paper presents the basics of life insurance, the method of calculating life insurance premiums and the application of IT in pricing the life insurance premium.
\end{abstract}

Keywords: IT, insurance premium, Python programming language, life table, life insurance.

\section{UVOD}

U ovom radu objašnjene su osnovne karakteristike životnih osiguranja i to tehničke osnove, pravni odnosi, vrste životnih osiguranja u Republici Srbiji, premija osiguranja, kao i zaključivanje ugovora o osiguranju života, prava i obaveza ugovornih strana i postupak naknade šteta.

Postoje mnoge vrste životnih osiguranja i sve su slične prema predmetu osiguranja ali se sve one razlikuju prema načinu izračunavanja svih uplata i isplata ili samog izračunavanja tarife. Dakle, svaka vrsta osiguranja poseduje svoju tarifu osiguranja. Zavisnosti od osiguravajuće kompanije, te tarife uzimaju određenu kamatnu stopu koja se po pravilu ne menja dužeg vremenskog perioda.

$\mathrm{U}$ radu su takođe proučavane oblasti finansijske matematike, aktuarske matematike, tablica smrtnosti i nekoliko vrsta proizvoda životnih osiguranja.

Sprovedeno je i istraživanje i primena aktuarske matematike na proizvode životnih osiguranja i razvijena su četiri matematička modela primenom Python programskog jezika.

\section{NAPOMENA:}

Ovaj rad proistekao je iz master rada čiji mentor je bila doc. dr Ljiljana Popović.
To su verovatno trajanje života, srednje trajanje života, kao i dva proizvoda osiguranja, jednokratna premija za neposrednu doživotnu ličnu rentu i godišnja privremena premija za doživotno osiguranje kapitala za slučaj smrti.

\section{PREMIJA U OSIGURANJU ŽIVOTA}

Osnova za tehničku mogućnost sprovođenja osiguranja za životno osiguranje, i za izračunavanje tehničke premije su tablice smrtnosti, kamatna stopa i troškovi sprovođenja osiguranja.

\subsection{Tablice smrtnosti}

Tablice smrtnosti su zasnovane na statistici. One se mogu primeniti na stanovništvo koje se želi osigurati. Tablice smrtnosti ili drugačije, tablice mortaliteta sadrže niz pokazatelja kao što su broj posmatranih stanovništva, broj umrlih, izravnata verovatnoća smrti, verovatnoća doživljenja, broj živih, broj mrtvih, zbir brojeva živih, srednje trajanje života i slično.

Pravilno postavljene računske osnove je uslov za sigurnost u poslovanju osiguranja života, i to osiguranje mora biti zasnovano na sigurnoj i tačnoj računskoj osnovi, koju predstavljaju blagovremene i precizne tablice smrtnosti.

\subsection{Kamatna stopa}

Pored tablica smrtnosti, kamatna stopa je drugi element potreban za izračunavanje tehničke premije. Red veličina kamatne stope se kreće oko 3, 4 i 5 \%. Pri izboru kamatne stope treba imati u vidu da kamatna stopa koja se odabere kao računski osnov za obračun tarifa (obračunska kamatna stopa), treba da bude niža od stope prinosa koju kroz ulaganja sredstava rezervi osiguravajuće društvo može da dobije.

Da bi se ostvarilo to da, prihodi od plasmana osiguravaču će biti veći od njihove kamatne stope, oni treba da koriste nešto nižu stopu od aktuelne kamatne stope - koja se u skladu sa tržišnim uslovima menja na više ili na niže. Kamatna stopa ne bi trebala da se menja često iz razloga što su ugovori u životnom osiguranju višegodišnji, a premija osiguranja je fiksna.

Prema preporuci Međunarodne Asocijacije Aktuara (International Actuarial Association), obračunska (tehnička) kamatna stopa se zasniva na očekivanoj stopi prinosa na imovinu čiji novčani prilivi treba da obezbede pokriće obaveza po osnovu ugovora o osiguranju [1]. 


\subsection{Troškovi sprovođenja osiguranja}

Kao treći element za izračunavanje tehničke premije uzimamo u obzir troškove sprovođenja osiguranja. Ovi troškovi su zajednički za sve privredne subjekte i karakteristični su za delatnost osiguranja.

Postoje tri vrste ovih troškova, i to su [2]:

1. Troškovi pribavljanja osiguranja ili akvizicioni troškovi

2. Inkaso troškovi

3. Administrativni ili tekući upravni troškovi

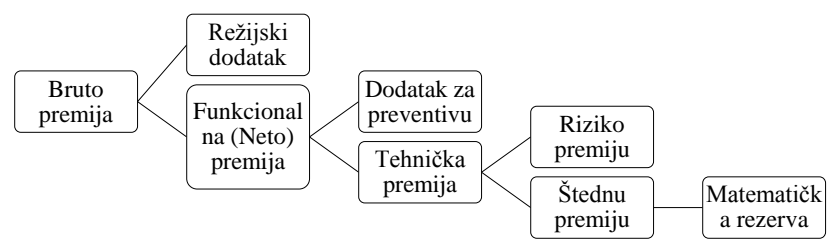

Slika 1. Podela bruto premije u životnom osiguranju [3]

\section{PRORAČUN PREMIJE ŽIVOTNOG OSIGURANJA}

Za proračun premije životnih osiguranja neophodno je pre svega definisati sledeće parametre koji su osnovni elementi tablica smrtnosti:

$x$ - Starost posmatranog lica

$\mathrm{L}_{\mathrm{x}}$ - Broj posmatranih stanovnika iz popisa stanovništva Republike Srbije iz 2011. godine.

$\mathrm{T}_{\mathrm{x}}$ - Broj umrlih stanovnika iz popisa stanovništva Republike Srbije iz 2011. godine.

$\mathrm{q}_{\mathrm{x}}$ - Verovatnoća smrti u narednoj godini.

$$
q_{x}=\frac{T_{x}}{L_{x}}, \text { odnosno } q_{x}=\frac{d_{x}}{l_{x}}
$$

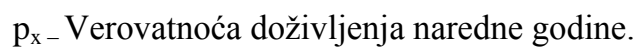

$$
p_{x}=1-q_{x} \text {, odnosno } p_{x}=\frac{l_{x+1}}{l_{x}}
$$

$\mathrm{Na}$ osnovu dobijenih vrednosti broja živih i broja mrtvih kao i odgovarajuće kamatne stope, izračunavaju se komutativni brojevi, koji služe kao osnova za izradu tarifa životnog osiguranja:

$1_{\mathrm{x}}-$ Broj živih lica

$$
l_{x+1}=l_{x}-d_{x}
$$

$\mathrm{d}_{\mathrm{x}}-$ Broj umrlih lica

$$
d_{x}=\frac{T_{x} \cdot l_{x}}{L_{x}}, \text { odnosno } d_{x}=l_{x}-l_{x+1}
$$

\subsection{Obračun premije životnih osiguranja primenom komutativnih brojeva}

Obračun premije životnih osiguranja primenom komutativnih brojeva biće prikazan na primeru jednokratne premije za neposrednu doživotnu ličnu rentu. Sam naziv neposredna doživotna lična renta govori da se radi o renti koju osiguranik prima od dana zaključenja ugovora o osiguranju dokle god je živ, na bazi uplate jednokratne premije (mize). Ova renta može biti anticipativna i dekurzivna [4]. Matematički posmatrano, premija osiguranja za pomenutu vrstu osiguranja se izračunava na sledeći način:

$$
l_{x} \cdot a_{x}=l_{x}+\frac{l_{x+1}}{r}+\frac{l_{x+2}}{r^{2}}+\frac{l_{x+3}}{r^{3}}+\cdots
$$

$\mathrm{S}$ obzirom da $l_{x}$ predstavlja ukupan broj osiguranika starih $x$ godina, pretpostavlja se da su se svi osigurali neposrednom doživotnom ličnom rentom. Sa $a_{x}$ označava se premija koju mora da uplati svako od $l_{x}$ lica da bi na početku svake godine dobijali po 1 dinar sve do kraja života.

Da bi se ispoštovao princip ekvivalencije - da je sadašnja vrednost jednokratne premije jednaka sadašnjoj vrednosti svih obaveza na dan zaključenja osiguranja, potrebno je da se izvrši diskontovanje svih isplata. Diskontovati neki iznos kapitala $\mathrm{K}$ znači umanjiti ga za interes za koji je taj kapital uvećan tokom $\mathrm{n}$ godina $\mathrm{i}$ svesti ga na njegovu sadašnju (početnu) vrednost [5].

Glavni problem korišćenja tablica smrtnosti može da nastane u slučaju kada klijent zahteva kamatnu stopu različitu od one koja je primenjena prilikom izrade tablica smrtnosti i komutativnih brojeva. Ovaj problem se može prevazići primenom informacionih tehnologija, što $u$ praksi nije čest slučaj, pa je samim time i kamatna stopa fiksna.

\subsection{Obračun premije životnih osiguranja primenom programskog jezika Python}

Python predstavlja višenamenski programski jezik koji u okviru svojih mogućnosti pruža podršku za veliki broj paradigmi koje se danas koriste $\mathrm{u}$ programiranju. Objektno-orijentisana paradigma predstavlja danas najzastupljeniju paradigmu prilikom razvoja softverskih rešenja [6].

Ukoliko bi želeli da izračunamo visinu gore pomenute premije osiguranja pomoću programskog jezika Python, komutativni brojevi postaju nepotrebni. Postavkom osnovnog algoritma za proračun mize $a_{x}$ moguće je izračunati premiju osiguranja unosom samo jedne promenljive, promenljive $l_{x}$.

$\mathrm{Na}$ ovaj način otvara se mogućnost manipulisanja (korigovanja) kamatne stope.

\subsection{Uporedni prikaz obračuna premije osiguranja primenom komutativnih brojeva i programskog jezika Python}

U nastavku rada je dat primer obračuna premije osiguranja za lice staro 95 godina, koje želi da osigura kapital, na način da svake godine prima rentu (R) u visini od 5.000 evra, od trenutka osiguranja pa sve do kraja života. Kamatna stopa je 3\%.

Premija je proračunata na dva načina, da renta bude $i$ anticipativna i dekurzivna. $\mathrm{Za}$ uporedni prikaz je korišćena premija za lice starosti 95 godina radi jednostavnosti proračuna premije pomoću komutativnih brojeva. 


\section{Primena komutativnih brojeva u obračunu premije}

Anticipativna renta:

$M=5000 \cdot a_{x}=5000 \cdot \frac{l_{95}+\frac{l_{96}}{r}+\frac{l_{97}}{r^{2}}+\frac{l_{98}}{r^{3}}+\frac{l_{99}}{r^{4}}+\frac{l_{100}}{r^{5}}}{l_{95}}$

$=5000 \cdot \frac{782+\frac{454}{1.03}+\frac{245}{1.03^{2}}+\frac{121}{1.03^{3}}+\frac{54}{1.03^{4}}+\frac{21}{1.03^{5}}}{782}$

$=5000 \cdot \frac{782+440.77+230.93+110.73+47.97+18.1}{782}$

$=5000 \cdot \frac{1630.538}{782}=5000 \cdot 2.0850869=10425.4345$

Dekurzivna renta:

$M=5000 \cdot a_{x}=5000 \cdot \frac{l_{96}+\frac{l_{97}}{r}+\frac{l_{98}}{r^{2}}+\frac{l_{99}}{r^{3}}+\frac{l_{100}}{r^{4}}}{l_{95}}$

$=5000 \cdot \frac{454+\frac{245}{1.03}+\frac{121}{1.03^{2}}+\frac{54}{1.03^{3}}+\frac{21}{1.03^{4}}}{782}$

$=5000 \cdot \frac{454+237.864+114.054+49.418+18.658}{782}$

$=5000 \cdot \frac{873.994}{782}=5000 \cdot 1.117639=5588.195$

Primena programskog jezika Python u obračunu premije

Anticipativna renta:

$$
\begin{aligned}
M=5000 \cdot a_{x} & =5000 \cdot 2.08508685755517 \\
& =10425.43428777585
\end{aligned}
$$

Dekurzivna renta:

$$
\begin{aligned}
M=5000 \cdot a_{x}= & 5000 \\
& \cdot 1.1176394632818252 \\
& =5588.197316409126
\end{aligned}
$$

Upoređeno rešenje pokazuje da algoritam radi tačno.

\section{ZAKLJUČAK}

Životno osiguranje ima veoma veliki značaj, uticaj i potrebu u svetu, pa i kod nas. Zato je veoma bitno kontinualno razvijati ovu granu industrije. Jedan od osnovnih pojmova u životnom osiguranju je premija, i njeno izračunavanje uz pomoć tarifa osiguranja. U ovom radu su opisani svi parametri koji utiču na visinu premije, kao što su kamatna stopa, troškovi pribave osiguranja i tablice smrtnosti. S obzirom da za svaku vrstu osiguranja koja postoji, koriste se drugačije matematičke formule, a one pripadaju aktuarskoj matematici, potrebno je dobro razumeti kako se kroz vreme vrše sve uplate i isplate, jer to predstavlja osnovu za izračunavanje tarifa.

Analizom stanja $u$ oblasti može se primetiti da nema radova koji se fokusiraju na izračunavanje tarifa, što je posledica posmatranja tarifa osiguranja kao poslovnom tajnom svake osiguravajuće kompanije. Primetno je i da tarife uvek imaju fiksnu kamatnu stopu, koja se ne može menjati.
Promena kamatne stope uzrokovala bi promenu svih vrednosti u tarifama. Iako se u svetu aktuarstva predlaže da se kamatna stopa ne treba menjati duži vremenski period, $u$ finansijski nestabilnim okruženjima korekcija je ipak neophodna. Naprotiv, postoji očigledan prostor za unapređenje koji se može rešiti prikazanim softverskim rešenjem. Ono ne samo da daje mogućnost da se bira interesni činilac pri izračunavanju premijskih parametara, već promenom samo jedne linije koda, može se implementirati eksploatacija drugih tablica smrtnosti. To znači da se ovo softversko rešenje može koristiti za različite tablice smrtnosti, dokle god dele obeležje. S druge strane, po istom principu može se razviti rešenje $i$ za druge modele životnih osiguranja. Izbor Python programskog jezika pokazao se kao zadovoljavajuć.

\section{LITERATURA}

[1] International Actuarial Association, „International Actuarial Association, Measurement of Liabilities for Insurance Contracts: Current Estimates and Risk Margins“, Ottawa, str.37, 2009.

[2] Lisov, M., \& Žarković, N. „Ekonomske i tehničke osnove osiguranja“. Novi Sad: FTN Izdavaštvo, Novi Sad. 2010.

[3] Petrović, M. Z., \& Dragan, M. „Životna osiguranja“, Beograd: "DIS PUBLIC", Beograd, 2005.

[4] Kočović, Mitrašević, \& Rajić, Aktuarska matematika, 2014, str. 59

[5] http://www.ekof.bg.ac.rs/wpcontent/uploads/2014/05/Prezentacija-Finansijskamatematika-za-master-studije-Compatibility-Mode.pdf (pristupljeno u junu 2019.)

[6] https://docs.python.org/3/index.html (pristupljeno $\mathrm{u}$ junu 2019.)

\section{Kratka biografija:}

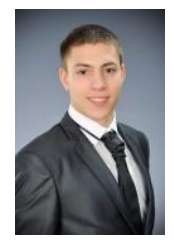

Pavle Mihajlović rođen je u Novom Sadu 1994. godine. Master rad na Fakultetu tehničkih nauka iz oblasti Inženjerski mendažment - Upravljanje rizicima i menadžment osiguranja odbranio je 2019.god.

kontakt: pavle.mihajlovic@gmail.com 